\title{
Event Review
}

\section{London Revenue Management Club}

Journal of Revenue and Pricing Management (2006) 5, 251. doi:10.1057/palgrave.rpm.5160046

The Revenue Management Club held its 11th meeting on the 18th May, at the London Marriott Marble Arch. The Revenue Management Club, which was started in January 2003, now has over 45 member companies, and continues to grow - it is also now formalizing its renaming as the Revenue Management Society.

The meeting included presentations from Svend Jansen of Opodo, George Pickard of Marriott Hotels, Dave Pearce from Virgin Trains.

Svend described the challenges of adapting the traditional Revenue Management techniques and thinking to the On Line Travel Agent sector, where some of the constraints such as fixed and perishable inventory and replaced by a range of other, new complications.

George Pickard of Marriott Hotel described how Marriott has improved their demand tracking system. Like many industries, in light of the fast growth of Internet and GDS enquiries, a new way of demand forecasting was needed to update the forecasts, which had previously been based on direct enquiry volumes. Among a number of sophisticated improvements is the introduction of statistically based 'turndown' rules, on which the demand forecast, and hence revenue management decisions, are now derived.
Dave Pearce from Virgin Trains described the progress on the introduction of Revenue Management in the rail industry. With the National Reservation System now bedded in, there is now increased scope to extend the use of Revenue Management, but within the existing constraints, such as the purchase restrictions, walk on (and stand) fares and the ever challenging issue of counting passengers on crowded trains.

Jutta Moore, who is a specialist RM and elearning, facilitated a questionnaire and discussion, to explore the demand and scope for providing shared training resources. The aim is to both pool and develop a core set of RM training courses and materials, which would then be available to member organizations.

The Revenue Management Society is currently exploring formalizing links with the Revenue Management Club, France - which is now starting to hold meetings with a similar format as the UK meetings.

For further information on the Revenue Management Society, please visit our website at: www.revenuemanagement.org.uk

Tim Rosen Secretary 